\title{
Forum
}

\section{Designing Perpetual Conservation Agreements for Land Management}

\author{
Adena R. Rissman \\ Author is Assistant Professor, University of Wisconsin at Madison, Madison, WI 53706, USA.
}

\begin{abstract}
Conservation initiatives on working ranches balance flexibility for land management with restrictions to ensure protection over time. Conservation easements are a common tool for range conservation, but the perpetual nature of their individually negotiated rights and restrictions may present a challenge for adaptive land management. The evolution of conservation easement approaches to land management was addressed in a review of 52 grazing easements created by The Nature Conservancy (TNC) in California rangelands between 1973 and 2006 as well as through interviews with TNC staff. Easement terms related to land management increased in complexity over time, particularly for purchased easements on private land. Easements commonly contained restrictions on riparian or wetland management $(58 \%)$, residual dry matter $(50 \%)$, and type of animal permitted $(46 \%)$ but rarely restricted number of cattle or animal unit months $(4 \%)$. Flexibility was provided by easement terms such as exceptions for drought years and reference to best management practices, the easement holder's administrative discretion, and easement amendment. Interviews with TNC staff revealed an iterative process in which conservation easements remain relatively fixed once they are established, whereas subsequent easements incorporate lessons learned from easement monitoring, enforcement, management, and applicable science. Conservation easements with an adaptive approach would link compliance terms with conservation goals, require monitoring of those terms, and have a mechanism for altering land management based on monitoring results. All three of these realms present challenges for the conservation easement structure. Improvements could be made in easement terms, ecological monitoring, and stewardship to improve the effectiveness and adaptability of this tool for maintaining ecological function on working ranches.
\end{abstract}

\section{Resumen}

Iniciativas de conservación en ranchos en operación balancean por un lado la flexibilidad del manejo de la tierra y por otro, las restricciones para garantizar su protección a través del tiempo. La conservación de los derechos limitados es una herramienta común para la conservación de la tierra, pero la naturaleza permanente de sus derechos individuales y las restricciones existentes podrían ser un reto para contar con un manejo de tierra flexible. Se hizo una revisión de cómo ha evolucionado el enfoque de la conservación sobre los derechos limitados para el manejo de la tierra sobre 52 derechos de pastoreo proporcionados por The Nature Conservancy (TNC) en los pastizales de California entre los años 1973 y 2006 así como a través de entrevistas con el personal del TNC. Los términos de los derechos relacionados con el manejo de la tierra incrementaron en complejidad a través de los años, particularmente debido a la compra de derechos en tierras privadas. Los derechos comúnmente contienen restricciones en el manejo de aéreas rivereñas o humedales (58\%), materia seca residual (50\%), y el tipo de animal permitido $(46 \%)$ pero rara vez se limita el número de ganado o unidad animal por mes (4\%). La flexibilidad fue proporcionada de acuerdo al tipo de derecho, así como años de sequia y en referencia a las mejores prácticas de manejo, a la discreción administrativa del titular de los derechos y de la modificación de los derechos. Entrevistas con personal de TNC revelaron un proceso iterativo en el cual la conservación de los derechos permanecen relativamente fijos una vez que son establecidos, mientras derechos subsecuentes incorporan las experiencias aprendidas del seguimiento de los derechos, ejecución, gestión y ciencia aplicable. La conservación de los derechos con un enfoque de adaptación podría unir los términos de cumplimiento con las metas de conservación; la obligación de dar seguimiento a esos términos; y proporcionar un mecanismo para alterar el manejo de la tierra basado en el seguimiento de resultados. Cada una de estas áreas representa un reto para la conservación de la estructura de los derechos. Se podrían hacer mejoras en condiciones de derechos, seguimiento ecológico y la administración para mejorar la eficacia y la adaptabilidad de estas herramientas para mantener la función ecológica en ranchos en operación.

Key Words: California oak woodlands, grazing policy, land conservation, land trusts, policy instruments, range management, residual dry matter, working landscapes

\footnotetext{
Research was funded in part by the National Science Foundation Graduate Research Fellowship Program and the Rodney Johnson and Katharine Ordway Stewardship Endowment from The Nature Conservancy.

At the time of the research, Rissman was a PhD Candidate, University of California at Berkeley, Berkeley, CA 94611, USA.

Correspondence: Adena R. Rissman, 1630 Linden Drive, University of Wisconsin at Madison, Madison, WI 53706, USA. Email: arrissman@wisc.edu

Manuscript received 21 December 2008; manuscript accepted 15 October 2009.
}

\section{INTRODUCTION}

Threats to rangelands from conversion to residential development have motivated significant public interest and investment in private rangeland conservation (Brunson and Huntsinger 2008). Conservation easements have become a primary land conservation tool in an era focused on voluntary, incentivebased solutions (Fairfax et al. 2005). Conservation easements 
typically restrict development, mineral exploration, and other land uses that may negatively impact the purposes of the easement (Byers and Ponte 2005). When these restrictions are insufficient for protecting biodiversity and natural resources over the long term, conservation easements may also address land management. This presents an important question: How can conservation easements, which are perpetual agreements created at one point in time, provide the balance of specificity and flexibility necessary for protection and land management?

The tension between specificity and flexibility and the development of proxies for compliance is a theme throughout environmental policy and law (Fiorno 2006). Public agencies have long struggled with aligning permitted activities and economic uses with broad statements of purpose amidst changing public attitudes and mandates (Dana and Fairfax 1980). Public land grazing permits are one example of attempts to balance control and flexibility and set standards for grazing use (Nicoll 2007). Conservation easements attempt to strike this balance on private lands, posing similar dilemmas as on public lands, but in a different institutional, political, and economic context. Conservation easements are a particularly appealing tool for private rangelands because they are typically voluntary, maintain private ownership and traditional range uses, and provide a cash payment or tax reduction to help ranches remain viable economically (Anella and Wright 2004). The use of conservation easements has blossomed since the 1980s. Conservation easements are land use agreements between a landowner and a nonprofit organization or government easement holder (Gustanski and Squires 2000). They are individually negotiated and therefore have a "limitless" variety of terms related to permitted and restricted uses, tailored to specific landowners and properties (Barrett and Nagel 1996). Conservation easements typically include a statement of purposes, the rights and obligations of each party, and restrictions on land use. The Conservation Easement Handbook suggests that vague or ambiguous terms should be avoided and "detailed terms reduce the risk of conflicting interpretations" (Byers and Ponte 2005). But written agreements cannot anticipate all potential future events so a process for adaptation will always be required (Boyd et al. 2000). The nonprofit or government conservation easement holder is tasked with monitoring and enforcing easement terms.

Conservation easements are required to be perpetual to qualify for federal tax deductions. Perpetual restrictions offer a promise of protecting land for the future although even the goal of preventing development may prove problematic with changing societal goals (Mahoney 2002; Korngold 2007) and environmental or economic conditions (McLaughlin 2005). The extension of conservation easements beyond open space protection into ecological protection and land management poses an additional set of challenges (Merenlender et al. 2004). How can easement terms be written now that will ensure sustainable management over the long run? What mechanisms for flexibility are needed? How can conditions be monitored and enforced? These issues are particularly difficult when easements aim to protect species and habitats in nonequilibrium rangeland systems that may benefit from active management (Westoby et al. 1989; Marty 2005).
Empirical studies have begun to explore the influence of conservation easements on land management although no studies have previously examined rangeland conservation easements (Boyd et al. 2000; Mashour et al. 2005; Rissman et al. 2007a). Few studies have differentiated among conservation easements, and it is unknown how landowner characteristics and funding mechanisms influence easement terms. This research focused on the approach of a well-established easement holder to solving a difficult problem: drafting perpetual easements to incorporate land management terms for biodiversity protection and ecological function. The Nature Conservancy (TNC) is one of the country's largest nonprofit conservation easement holders (Rissman et al. 2007a). Conservation easements created by TNC in California rangelands were assessed to understand 1) easement terms on rangeland management and mechanisms for flexibility, 2) easement and landowner characteristics associated with easement terms, and 3) the implications of easement drafting, monitoring, and enforcement for adaptive range management.

Recently established easements were hypothesized to be more complex than older easements, incorporating detailed and quantitative terms related to grazing, invasive species, and prescribed fire. Mechanisms for flexibility were expected to increase over time along with the specificity in easement terms. Donated easements were expected to be less specific than easements that were purchased, retained by TNC when it transferred land, or exacted as part of a government regulatory requirement (i.e., Lippmann 2004) because easement holders may have less leverage in negotiating donated easements. Conservation easements on privately owned land were expected to be more specific than easements on public or nonprofitowned land. Easements over larger land areas were anticipated to be more detailed because of greater potential for multiple land uses and habitat features. Increases in specificity were hypothesized to occur over time as a result of TNC learning from previous experiences in which landowner actions on properties with nonspecific easements could not be addressed.

Finally, the potential for conservation easements to incorporate an adaptive management approach was analyzed relying on easement terms, monitoring reports, and interviews with TNC staff. Understanding the evolution of easements can illuminate needed modifications to a tool not originally designed for land management, as well as the changing expectations of conservation investments on private land.

\section{METHODS}

\section{Study Area}

California oak woodlands and grasslands have a Mediterranean climate with cool, wet winters and warm, dry summers. California rangelands are dominated by nonnative annual grasses but they continue to support high endemic plant and animal diversity (Pavlik et al. 1991). California rangelands are over $80 \%$ privately owned and cattle ranching is the primary commercial use (Huntsinger and Fortmann 1990). Many ranchers earn the majority of their income off-ranch and acquisition of ranches for recreational and amenity values is common (Brunson and Huntsinger 2008). Conservation of working ranches has gained increasing recognition in Califor- 
nia, and a complex array of private funders, public agencies, and land trusts is working to protect land in California (Rissman and Merenlender 2008).

\section{Easement Document Analysis}

Analysis of easement documents reveals trends in document complexity and the tension between specificity and flexibility for land management. Employing a geographic information system, I selected all easements held or created by TNC in oak woodlands or grasslands (California Department of Forestry and Fire Protection and US Forest Service 2002) that had or permitted livestock grazing based on TNC monitoring reports from 2005 to 2007 and that were located on a parcel of at least 8 ha (20 acres), resulting in a set of 52 grazing easements.

I completed an extensive questionnaire on easement purposes, threats, terms, and monitoring, drawing from the conservation easement and all exhibits, the easement documentation report, monitoring reports from 2005 to 2007, and an orientation narrative about each property created by TNC staff. Documents were accessed through TNC California's internal monitoring and reporting system, ConservationTrack $^{\circledR}$. Grazing management on rangelands involves decisions about the kind, class, timing, location, and intensity of grazing. Management of invasive species, fire, and water resources are also of particular concern for rangelands, and involve decisions about who is responsible for conducting management actions with what tools and on what portions of the property. I identified and coded easement terms related to these aspects of rangeland management. Variables were developed from the literature, reading easements, and discussing easement negotiations with TNC staff. Coding was coordinated and validated between two easement database recorders (Krippendorff 2004).

To develop an ordinal metric of easement complexity, I summed 13 terms related to grazing ( 6 terms), invasive species (5 terms), prescribed fire (1 term), and riparian or wetland management (1 term). Grazing terms included restrictions related to residual dry matter (RDM), season of grazing, type of grazing animal, management zones, number of animals or animal unit months (AUMs), and TNC rights to graze. Invasive species terms included prohibitions on planting invasives, the mention of invasive species management, TNC rights to conduct invasives management activities, specific methods permitted, and landowner approval constraints on TNC rights. Fire was typically discussed as a method for invasive plant management.

Terms were equally weighted, such that the final metric is weighted toward grazing and invasive plant management issues, recognized as two of the primary concerns in California oak woodlands and grasslands. Data analysis was completed in JMP 7.0 (SAS Institute, Cary, NC). I tested the relationship between easement complexity and easement establishment year (centered, year minus the median year 1990), easement property size (log hectares), and easement acquisition type, with a stepwise ordinal logistic regression (Agresti 2002). Including these variables in a multiple regression indicates the influence of easement acquisition type and property size while taking into account change over time. Easement acquisition type had three categories incorporated as dummy variables in regression analyses: easements on public or nonprofit-owned land $(n=11)$, easements on private land that were donated by the landowner $(n=12)$, and easements on private land that were purchased, retained when TNC transferred the land to a private landowner, or exacted by a government agency as mitigation $(n=29)$.

Mechanisms for flexibility in conservation easements were identified through reading easements and monitoring reports and consulting with TNC staff. Flexibility can result from easement terms, the easement holder's administrative discretion, and amendment of the easement. Finally, I analyzed compliance monitoring and enforcement efforts related to land management, relying on monitoring reports from 2005 to 2007 and on interviews with TNC staff.

For the 13 identified land management restrictions and six mechanisms for flexibility, I calculated the proportion of easements with each term. Logistic regression of each easement term over time indicates which terms are increasingly found in conservation easements. Range odds ratios provide the probability of an easement including a term divided by the probability of an easement not including a term over the range of dates (Agresti 2002). The proportion of easements with each term is compared, using $\chi^{2}$ tests, for easements purchased (or retained or exacted) on private land, donated on private land, or on public or nonprofit-owned land.

\section{Interviews}

Interviews with TNC staff elucidated their perspectives on the drivers behind easement terms. Staff from TNC's main California office identified the regional employee most familiar with each of the 52 grazing easements. This resulted in a list of seven staff members whom I interviewed. I asked these staff members to identify other employees knowledgeable about TNC's grazing easements, which resulted in an additional 15 contacts, of which 13 agreed to an interview. In total, I interviewed nine TNC science staff, nine TNC project staff, one TNC attorney, and one private consultant. Each interview was a 1-h semistructured phone interview. Interview questions focused on easement drafting, range management, easement monitoring, and the role of science in conservation practice. Information from these interviews is used to annotate the findings from easement document analysis and was not intended as a quantitative sample.

\section{RESULTS}

\section{Easement Characteristics}

The 52 conservation easements in the study (Fig. 1) were established between 1973 and 2006. Two were established in the 1970s, five in the 1980s, 14 in the 1990s, and 31 in the 2000s. They ranged between 2 ha and 14600 ha (4-36000 acres), with a median size of 317 ha (780 acres). Seven were transferred to successor nonprofit or government easement holders with an ongoing TNC monitoring role.

The context for TNC's use of conservation easements in California rangelands changed dramatically between 1973 and 2006. In the 1960s and 1970s TNC employed deed restrictions, brief restrictions recorded with the deed with inconsistent enforcement rights. Nonprofit organizations gained the authority to hold conservation easements without government 


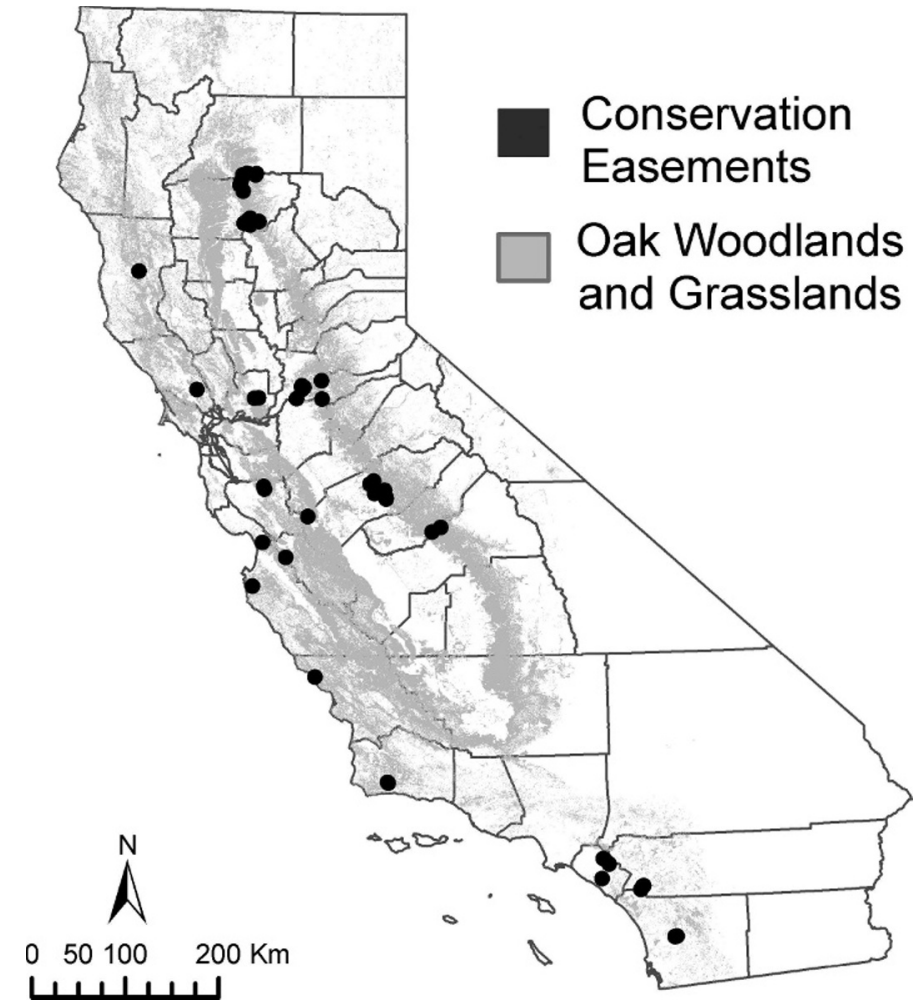

Figure 1. The Nature Conservancy's grazing conservation easements in California oak woodlands and grasslands.

approval in the California Conservation Easements Act of 1979 (Barrett and Livermore 1983). Early conservation easements were typically donated by private landowners or retained by TNC when it sold or donated lands to other conservation organizations. Through the 1990s and 2000s, conservation easements became TNC's primary acquisition tool, allowing the organization to work at larger scales on private lands, and easements shifted from being mostly donated to mostly purchased. Payments to landowners for purchased easements ranged from hundreds of thousands to over one million dollars. ConservationTrack ${ }^{\circledR}$ was established in 2004 to provide an internal online tracking system for easement monitoring.

\section{Easement Complexity}

Summation of land management terms related to grazing, invasive species, prescribed fire, and riparian and wetland areas reflects easement complexity and detail. Nearly all land management terms became significantly more common over time (Table 1). Consistent with expected results, easements purchased, retained, or exacted on private land contained significantly more land management terms than easements on public or nonprofit-owned land or donated easements on private land (Table 1). Multiple ordinal logistic regression indicated that establishment date, method of acquisition, and property size all had significant influences on easement complexity (Table 2).

Changes in easement specificity and detail over time were incremental but shifted most in the mid-1990s. Interviews revealed several explanations for these trends. Increases in easement complexity resulted from the accumulation of knowledge and experience over time as TNC staff and landowners sought answers for the question, "what if, what if?" What if ranchers need to change their grazing practices over time? What if a future landowner wants to use the ranch in ways that may be harmful to the conservation purposes? Interviewees attributed less-specific easement terms on public and nonprofit-owned land than on private land to an assumption of shared goals between organizations.

\section{Ranching Terms}

Easements across the time period that mentioned grazing generally included broad statements of compatibility between grazing and the conservation purposes of the easement. Over time easements incorporated more specific restrictions on grazing. None of the easements required grazing.

The incorporation of minimum RDM terms beginning in 1997 was a dramatic shift toward quantitative standards for range management, particularly for purchased, retained, or exacted easements on private land (Table 1). RDM is the amount of dry litter remaining at the end of the grazing season, measured in pounds per acre before the fall rains (Bartolome et al. 2002). Minimum RDM levels were between $448 \mathrm{~kg} \cdot \mathrm{ha}^{-1}$ and $1345 \mathrm{~kg} \cdot \mathrm{ha}^{-1}\left(400-1200\right.$ pounds $\cdot$ acre $\left.^{-1}\right)$. Most required a minimum such as $673 \mathrm{~kg} \cdot \mathrm{ha}^{-1}$ or $897 \mathrm{~kg} \cdot \mathrm{ha}^{-1}$ (600 or 800 pounds $\cdot$ acre $^{-1}$ ) averaged across the entire property whereas some had a $448-\mathrm{kg} \cdot \mathrm{ha}^{-1}$ (400 pounds $\cdot$ acre $\left.^{-1}\right)$ pasture minimum. One easement stipulated that if the property is grazed, it must be grazed within a minimum and a maximum range of RDM. In this case a TNC ecologist recommended grazing to reduce standing thatch in order to protect vernal pool species.

TNC staff indicated that RDM became a common compliance term because it is directly linked to grazing pressure, creates a shared language with landowners, and is relatively inexpensive to monitor. Furthermore, interviewees suggested that RDM terms were motivated by demand for standards and accountability by TNC and public and private funders. However, every interviewee familiar with RDM terms also expressed reservations about their efficacy. RDM terms do not reveal many important range conditions such as soil productivity, abundance or diversity of native plants, status of native animals, water quality, or oak regeneration. RDM provides reactive, rather than proactive, management and consultation.

Many easements restricted the type of grazing animal to cattle and sheep, with horses, burros, and mules permitted as necessary to service the grazing operation. Ten easements specifically mentioned that goats can be used for weed control. Many allowed for additional types of animals with TNC's discretionary consent. Early experiences with landowners interested in grazing ostriches led TNC staff to include this term, preferring grazing animals with well-researched grazing impacts.

In easements that restricted the season of grazing, the permitted start of the grazing season fell between 1 October and 1 December, and ended between 10 April and 30 June, depending on regional differences. Staff mentioned that restricting grazing to the winter wet season was particularly important given research showing that cattle shift to riparian areas and more often browse oaks in the summer. Some thought year-round grazing operations were more prone to overgrazing and potential easement violations. 
Table 1. Increase over time and difference among acquisition categories for conservation easement terms and complexity metric $(n=52)$. Bold probability values highlight variables exhibiting significant increase over time at $P<0.050$.

\begin{tabular}{|c|c|c|c|c|c|c|c|}
\hline & \multirow[b]{2}{*}{ Easements \% } & \multicolumn{3}{|c|}{ Increase over time } & \multicolumn{3}{|c|}{ Acquisition category } \\
\hline & & $\chi^{2}$ & $P$-value & $\begin{array}{l}\text { Range odds } \\
\text { ratio }\end{array}$ & $\begin{array}{l}\text { Purchased on } \\
\text { private land }\end{array}$ & $\begin{array}{c}\text { Public or } \\
\text { nonprofit land }\end{array}$ & $\begin{array}{l}\text { Donated on } \\
\text { private land }\end{array}$ \\
\hline Grazing: $\mathrm{RDM}^{1}$ & $50 \%$ & 15.65 & $<0.001$ & 2755 & $76 \%^{2}$ & $18 \%$ & $17 \%$ \\
\hline Grazing: animal type & $46 \%$ & 16.11 & $<0.001$ & 6799 & $76 \%^{2}$ & $18 \%$ & $0 \%$ \\
\hline Grazing: TNC right & $44 \%$ & 19.50 & $<0.001$ & 8409 & $69 \%^{2}$ & $27 \%$ & $0 \%$ \\
\hline Grazing: zones & $38 \%$ & 1.85 & 0.174 & - & $55 \%$ & $9 \%$ & $25 \%$ \\
\hline Grazing: season & $31 \%$ & 3.95 & 0.047 & 28 & $41 \%$ & $9 \%$ & $25 \%$ \\
\hline Grazing: number of animals or AUMs & $4 \%$ & 0.04 & 0.834 & - & $7 \%$ & $0 \%$ & $0 \%$ \\
\hline Invasives: no planting & $81 \%$ & 8.78 & 0.003 & 56 & $90 \%$ & $73 \%$ & $67 \%$ \\
\hline Invasives: management mentioned & $75 \%$ & 20.85 & $<0.001$ & 2187 & $86 \%$ & $82 \%$ & $42 \%$ \\
\hline Invasives: TNC right & $65 \%$ & 14.84 & $<0.001$ & 395 & $76 \%$ & $64 \%$ & $42 \%$ \\
\hline Invasives: specific methods & $63 \%$ & 5.49 & 0.019 & 19 & $79 \%$ & $55 \%$ & $33 \%$ \\
\hline Invasives: Iandowner action & $21 \%$ & 5.59 & 0.018 & 393 & $35 \%$ & $9 \%$ & $0 \%$ \\
\hline Prescribed fire: management mentioned & $77 \%$ & 21.19 & $<0.001$ & 3000 & $90 \%$ & $82 \%$ & $42 \%$ \\
\hline Riparian/wetland protection & $58 \%$ & 4.38 & 0.037 & 14 & $72 \%^{2}$ & $27 \%$ & $50 \%$ \\
\hline Discretionary consent terms & $85 \%$ & 0.51 & 0.479 & - & $82 \%$ & $72 \%$ & $100 \%$ \\
\hline RDM consultation $^{3}$ & $77 \%$ & 4.73 & 0.030 & 65 & $82 \%$ & $100 \%$ & $0 \%$ \\
\hline Management plan & $29 \%$ & 6.02 & 0.014 & 138 & $17 \%$ & $64 \%$ & $25 \%$ \\
\hline Best management practices & $29 \%$ & 5.10 & 0.024 & 81 & $48 \%$ & $9 \%$ & $0 \%$ \\
\hline Amendment clause & $23 \%$ & 10.23 & 0.001 & 19720 & $28 \%$ & $36 \%$ & $0 \%$ \\
\hline Drought exceptions & $15 \%$ & 0.72 & 0.396 & - & $17 \%$ & $0 \%$ & $25 \%$ \\
\hline \multicolumn{8}{|l|}{ Complexity metric (median; ordinal } \\
\hline regression) & 7 & 27.3 & $<0.001$ & na & 9 & 6 & 2.5 \\
\hline
\end{tabular}

${ }^{1}$ RDM indicates residual dry matter; TNC, The Nature Conservancy; AUM, animal unit month; and na, not applicable.

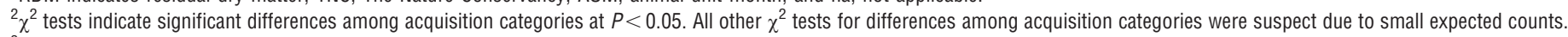
${ }^{3} \mathrm{RDM}$ consultation as a percentage of the 26 conservation easements that have an RDM term $(n=26)$.

Two easements established in 1998 and 2000 restricted the number of grazing animals or AUMs. These terms arose in the negotiations in each case, and did not reflect a programmatic decision on the part of TNC. Restrictions on number of animals or AUMs were not considered effective by TNC staff, one of whom noted, "If you had a set stocking rate on some years you wouldn't even be scratching the grazing potential but other years you would be grossly overgrazing." TNC staff indicated this term is difficult to monitor on sizable properties. Land management zones varied in characteristics and included labels such as rangeland, compatible use, irrigated pasture, farm area, riparian area, sensitive aquatic resource area, wetland area, wilderness use zone, special management zone, and forest area. Zones were typically mapped in exhibits to the easement.

Rights held by TNC also increased significantly over time (Table 1). In $44 \%$ of easements, TNC had the right to graze

Table 2. Stepwise ordinal logistic regression of a complexity metric for conservation easement land management terms $\left(\chi^{2}=40.92, P<0.001\right.$, - LogLikelihood =99.98, $n=52$ ).

\begin{tabular}{lcrc}
\hline \multicolumn{1}{c}{ Parameter } & Estimate & \multicolumn{1}{c}{$\chi^{2}$} & $P$-value \\
\hline Year established (centered around 1990) & -0.1646 & 13.34 & 0.0003 \\
Easement size (log ha) & -0.7571 & 6.09 & 0.0136 \\
Purchased on private land & -0.7403 & 6.18 & 0.0129 \\
\hline
\end{tabular}

cattle as an ecological management tool to control nonnative species if the landowner chose not to graze, and in an additional $13 \%$ (7 of 52), TNC had the right to control nonnative species with methods that did not mention, but did not preclude, cattle grazing. TNC's grazing rights were typically constrained by landowner approval, which could not be unreasonably withheld. None of the interviewees knew of a case in which TNC had arranged to graze an easement property. However, TNC encouraged several absentee landowners to continue leasing their properties in order to maintain an active presence on the property, support the local ranching community, and reduce invasions of yellow star thistle (Centaurea solstitialis L.) and medusahead (Taeniatherum caput-medusae [L.] Nevski).

\section{Invasive Plants, Prescribed Fire, and Wetlands Management}

None of the easements created before 1990 referred to invasive species management, compared with $90 \%$ of those created after 2000. However, some of the earliest easements from the 1980s included a prohibition on planting invasive species. TNC rights to manage invasives were constrained by landowner approval in two-thirds of the easements where it was mentioned (23 of 34). For example, one easement gives TNC the right but not the obligation "to eliminate non-native species from the Property through the use of biocides, prescribed burns, and other reasonable means." Easements referred to the following tools to reduce invasive species: chemical control through biocides (27 easements), prescribed fire (24 ease- 
ments), grazing (22 easements), and mechanical control (3 easements). TNC staff indicated they provide invasive species management advice to landowners and have helped landowners implement invasive species control.

Prescribed burning is another significant management tool in California oak woodlands and grasslands. Nearly all easements that mentioned invasive species management also mentioned prescribed burning. In 31 easements, TNC had the right to implement prescribed burns. Of these, 24 indicated that landowner approval is required and may not be unreasonably withheld, 3 were subject to landowner approval with no qualification, and 6 did not mention landowner approval. Regardless of easement language, all interviewed staff indicated that a prescribed burn would only be conducted with landowner approval.

Riparian and wetland management terms were included throughout the study period, from the 1970s through the 2000s. Examples included buffers around vernal pools that could not contain salt licks, food supplements, or new roads unless there were special circumstances involved; higher RDM requirements in riparian areas; requirements for fencing riparian areas; limits on grazing near creeks; and specifications for new stream crossings.

\section{Mechanisms for Flexibility}

Primary mechanisms for flexibility resulted from easement terms, the easement holder's administrative discretion, and easement amendment. Easement terms that provided flexibility included provisions for consultation after RDM violations, references to best management practices, management plans, and drought-year exceptions. Most easements with RDM requirements indicated that if RDM levels were below the minimum, consultation would be required to set grazing levels for the following year. RDM violations without this consultation language would rely on the easement's more general terms for remedying violations, which could include mediation or arbitration. Some also included a process for remeasuring RDM and relying on third-party experts in the case of a disagreement. Best management practices terms were used to set general guidelines. For example, easements might state that ranching operations shall be consistent with best management practices for livestock in the general geographic area of the ranch.

All easements with management plans were on public or nonprofit-owned land, or were written with the assumption that the land would later be transferred to a public agency. Several required management plans to be created under certain conditions, such as before grazing occurs, before TNC can build new fences on the property; or before restoration can occur. Existing management plans were for general resource management, for the California tiger salamander (Ambystoma californiense), or related to multiple-species habitat conservation plans. Several of the easements with management plans were mitigation properties with management plans required by government agencies. One required restoration plan had yet to be completed between the landowner and the US Fish and Wildlife Service, due to stalls in approving the plan and associated management funds. Three easements on one landowner's property referenced management plans, but the parties have been unable to agree on management plan terms since the easements were established in the early 2000s. Management plans were not a preferred tool among TNC staff. The primary reason given was that they did not have the resources to update management plans and renegotiate terms for all their properties every few years. Staff felt some issues were "punted" to an incomplete management plan to allow the deal to be closed, and they were frustrated with still negotiating those issues years later. They also raised questions about enforceability of management plan terms within an easement structure. Some also felt that their role was not to manage the property at the level of detail of a management plan, but just to provide sufficient restrictions in the easement to prevent degradation.

Drought-year exceptions varied and became more clearly defined over time. A donated easement from the 1980s provides an example of an early easement approach to management in drought years. In this case, TNC's right to determine what levels of grazing might adversely affect the property was limited by the recognition that the property was overgrazed in the drought years of 1977-1979 "more than either Donor [the landowner] or the Conservancy [TNC] would have preferred. It is understood that such conditions might recur in future years." Interpretation of this easement language for future grazing management is likely to hinge on whether future grazing levels are greater than historic levels. In this case, historic grazing levels and drought conditions were referenced but not defined.

Five easements since the late 1990s had more specific drought exceptions, such as reducing minimum RDM levels to $448 \mathrm{~kg} \cdot \mathrm{ha}^{-1}$ (400 pounds $\cdot$ acre $^{-1}$ ) in drought years. Only three easements defined a drought year, and those referenced guidelines from the Natural Resources Conservation Service (NRCS) or its successor agency. One easement simply stated in the RDM paragraph that "periods of drought shall be considered" but did not specify how. This vague language has not been helpful in settling a dispute over grazing levels in dry years.

One common mechanism for easement flexibility through administrative discretion was the inclusion of terms that allow for modification of permitted uses with TNC approval in the future, which would not seemingly require an amendment of the conservation easement. Discretionary consent clauses were particularly common for allowing additional types of grazing animals, extension of the grazing season, new roads for the ranching operation, or the use of biocides. One easement included a special section requested by the landowner that stipulates that grazing management terms may change every $25 \mathrm{yr}$ in accordance with changed conditions and published scientific advances.

One option for flexibility over time is amendment by mutual agreement of the parties. Few of the easements have been amended, although one was substantially reinterpreted because it was written for a private landowner and subsequently the property was given to a public agency for research and education. Amendment is not a desired option among TNC staff: "we try to build whatever we can in so we're not amending these easements in 10 years." Easements without an amendment clause that permits future amendment could potentially be amended as well, but donated easements face additional scrutiny related to charitable trust law. 


\section{Compliance Monitoring and Enforcement}

All easements were monitored for compliance in 2006 and 2007 with a minimum of an annual site visit to the property. In cases where properties fell below RDM limits, TNC consulted with the landowner on future management. In one example, a consultant with local knowledge was hired to monitor several easements in a county. In one year, many of these easements were below the drought year limit of $448 \mathrm{~kg} \cdot \mathrm{ha}^{-1}(400$ pounds $\cdot$ acre $\left.^{-1}\right)$. Variability in the measurement technique led the consultant and TNC staff to conclude that several easements with $404-437 \mathrm{~kg} \cdot \mathrm{ha}^{-1}$ (360-390 pounds $\cdot$ acre $^{-1}$ ) were being managed well and were not out of compliance given the circumstances, but that additional actions needed to be taken on one ranch with RDM under $168 \mathrm{~kg} \cdot \mathrm{ha}^{-1}(150$ pounds $\left.\cdot \operatorname{acre}^{-1}\right)$. This led to a meeting with the landowner, lessee, and TNC staff to work on ways to improve management in the future. Other issues included disputed definitions of drought years if they were not defined in the document, and claiming that hay brought onto the rangeland should be included within the RDM count. No easement violations were adjudicated in court.

\section{DISCUSSION}

Conservation easements address land management in an attempt to ensure that rangeland use will not degrade conservation values. But perpetual contracts may be poorly tailored for land management. Given the ongoing reliance on conservation easements for private land conservation, an organization with three decades of experience drafting, monitoring, enforcing, and adapting conservation easements provides important lessons for rangeland conservation and management.

This study examined conservation easements with biodiversity conservation goals in Mediterranean-climate rangelands with high annual variability that may benefit from active management. In these circumstances, easements evolved to address active management by incorporating quantitative resource standards, mechanisms for flexibility, and easement-holder rights to implement land management. Land management terms increased in specificity over time, particularly for purchased, retained, or exacted easements on private land. These methods of acquisition provided the easement holder greater leverage in negotiating terms than did donated easements, which has important implications for understanding the outcomes of alternate funding mechanisms. As anticipated, easements on public or nonprofit-owned land were less detailed and specific than easements on private land, which may indicate assumptions of common goals, fewer threats, and professional relationships with other government and nonprofit organizations.

Although I expected to find that specificity increased because TNC staff perceived that older easements were not detailed enough to prevent resource degradation, I found a more complicated explanation. The evolution in easement language was affected by the organization's shift to easements as a primary strategy; increases in TNC attorney, project manager, and scientist experience; improved understanding of species' habitat needs; increasing landowner sophistication; and greater public funding and demands for accountability. Landowners also sought to specify easement terms in detail to obtain certainty about future permitted uses.

Once an easement was established, there were a limited number of mechanisms for flexibility over time. Most modifications within the easement holder's discretion were made informally through consent and ongoing conversations with landowners. Management plans are a common mechanism for providing land management flexibility among land trusts and TNC chapters outside of California (Rissman et al. 2007a), but in this study area they were employed in less than one-third of easements, with mixed results. In concept, management plans can be easily updated over time, but they raise questions about enforceability, conflict resolution and negotiation, and public access to information because they are not recorded with the easement. Easement amendment also allows for change over time, but raises a variety of red flags, particularly in the wake of increased scrutiny of conservation easements by Congress and the Internal Revenue Service, and abuse of easement amendments and terminations (McLaughlin 2005; Land Trust Alliance [LTA] 2007). TNC's standard operating procedure requires that amendments not diminish the goals of the original conservation easement (LTA 2007). Amendments that increase the economic value of the property to the landowner would require the landowner to compensate the easement holder.

What are the implications of conservation easementsstructured by rights and responsibilities, compliance monitoring, and enforcement-for adaptive management? A true adaptive management system involves altering management as a result of monitoring feedback, and may treat management approaches as experiments (Wilhere 2002). An easement that incorporates an adaptive approach would at a minimum have compliance terms linked to conservation goals, require monitoring of these terms, and have a mechanism for altering future management decisions based on monitoring results. All three of these realms present challenges for the conservation easement structure.

Easement terms highlight the common disconnect between resource goals and compliance or evaluation measures, which permeates efforts to manage rangeland use on public and private lands (Task Group on Unity in Concepts and Terminology Committee Members 1995; Stubble Height Review Team 2006). Quantitative biodiversity indicators are arguably more objective, reliable, replicable, and communicable than subjective measures. Yet no proxies for biodiversity served as compliance terms in conservation easements because biodiversity goals are difficult to define and operationalize and landowners generally cannot be held responsible for maintaining native plant diversity or animal populations. Conservation easements in this study aimed to prevent overgrazing by restricting RDM, season of grazing, type of grazing animal, and number of grazers. These terms are expected to promote the conservation goals of the easement, but that assumption is not tested directly. Environmental regulations must define compliance terms, but compliance is often recognized as a "narrow measure of performance" (Fiorino 2006).

Conservation easements-like all environmental policies and regulations-are subject to both linguistic and epistemic uncertainty (Regan et al. 2002; Doremus 2007). Borderline cases create vagueness that is inherent in language and categorization. A vague attempt to prevent overgrazing might state that grazing should not degrade rangeland conditions. 
This provides little guidance for management and places the burden of proof on the easement holder. Recognizing these limitations, quantitative standards such as RDM were developed. RDM is a well-established compliance monitoring term for annual grasslands used in public land grazing permits and by private landowners seeking to restrict lessee grazing (East Bay Regional Park District 2001; Bartolome et al. 2002). The drought-year RDM enforcement example indicates that TNC enforces RDM standards using contextual information and not as a strict benchmark for compliance. RDM does not represent all resource protection goals, was drafted into easements with numerous variations, and was monitored with a variety of methodologies. "Drought year" is another vague term subject to the problems of a borderline case. Reference to NRCS guidelines for drought years provides a dynamic basis for defining drought conditions (Greene 2005).

Epistemic uncertainty, due to incomplete knowledge, also impacts easement drafters' ability to address land management. The evolution toward detailed and quantitative standards highlights the important role played by scientists in crafting easement terms. Easement drafting decisions subject to uncertainty include deciding which species and habitats to list as conservation values, which threats have the potential to harm those species, and what use restrictions are required to prevent that harm. In negotiation, staff must have a sense of priorities to know where to compromise. The ecological sciences that underpin these decisions are inherently iterative and cannot provide omniscient direction for policy (Carden 2006). Nonequilibrium ecology predicts that vegetation changes are driven more by abiotic factors such as temperature and rainfall rather than biotic interactions such as grazing (Westoby et al. 1989). This complicates efforts to link management practices with vegetation change- the type of causal relationship that lends itself to rational regulation. If new easements are better tailored to current conditions, then older easements are more poorly tailored and will become even less current over time. These issues are a particular concern given the potential impact of global climate change on arid and semiarid ecosystems (e.g., Kueppers et al. 2005).

Although all easements were monitored for compliance, the lack of long-term monitoring beyond compliance for most conservation easements is another gap in the cycle of adaptive management (Rissman et al. 2007b). RDM is an interesting exception to this lack of monitoring, because it is a compliance term linked to preventing overgrazing that is monitored annually. There is evidence that consultation after RDM violations engages the landowner and the easement holder in a discussion that can influence future management decisions. Funding for ecological monitoring is necessary for linking compliance terms with conservation goals.

"Property is persuasion" and TNC's management rights are exercised in the context of a social contract with the landowner (Macpherson 1978; Rose 1994). Social relations between easement holders and landowners are likely to be central to conservation easements' success (Huntsinger and Hopkinson 1996). Rangeland landowners have a diversity of perspectives on private property and surveys have indicated that ranchers feel a personal stewardship responsibility but reject the idea that natural resources on their land belong to society (JacksonSmith et al. 2005). Future research could examine whether landowners view the partial property rights arrangements created by conservation agreements as an erosion of property rights and whether these arrangements influence landowners' willingness to implement conservation practices without compensation (Kreuter et al. 2006).

TNC staff viewed restrictions on landowner actions as insufficient to sustain biological diversity, so TNC's easements evolved to acquire rights to undertake active land management and ecological research. Others have similarly found that affirmative rights to manage land may be critical to meeting easement goals (Ohm 2000). When management resources are abundant, easement holders could serve as comanagers of natural resources with the landowner, sharing property rights and responsibilities.

Land trusts have an incentive to act moderately in enforcing land management violations both because of their often-shared vision with landowners, and out of a desire to acquire more easements in the future. Ultimately, if conservation easements are challenged they must be enforced through the adversarial court system. There may be political pressures on easement holders not to enforce restrictions that are unpopular with private landowners. In these cases the public interest in the rights granted through conservation easements will be fundamental to the public will to enforce their terms. Conservation easements are emblematic of a shift toward privately negotiated contracts for environmental protection (Camacho 2007). The contractual model allows for learning and adaptation from one contract to the next, but each easement has relatively fixed terms, with limited mechanisms for updating over time. A clear and transparent process for making reasonable changes to easement terms would allow for updating and adaptation over time while ensuring resource protection and sustainable rangeland use.

\section{IMPLICATIONS}

Despite innovations in flexibility for land management, the paradox of perpetual restrictions for adaptive management remains. It is a mistake to assume that once an easement negotiation is complete, the land will remain in a static, "protected" status. If rangeland conservation easements do not address land management they may fail to sustain natural resources and biological diversity. If in the other extreme, easements bind land management too strongly, they will be trapped in the same narrow focus on control that has hampered other resource management initiatives (e.g., Holling and Meffe 1996, Langston 2003). Rather than providing an alternative to environmental regulation, conservation easements shift governance authority to negotiated, perpetual agreements subject to many of the same uncertainties common in public land policy. Systems for updating and adaptation that address the easement's purpose, landowner needs, and public investment are needed. Closer relationships between natural resource scientists, rangeland extension specialists, and conservation decision-makers could improve the incorporation of scientific knowledge into perpetual easement terms and the creation of adaptive monitoring and management approaches.

\section{ACKNOWLEDGMENTS}

Many thanks to Adina M. Merenlender, Sally K. Fairfax, and Nathan Sayre from University of California Berkeley; Rich Reiner and Lynn Lozier of The 
Nature Conservancy for their valuable contributions to study design and manuscript review; Rebecca Shaw, Peter Kareiva, The Nature Conservancy Range Group, and all the staff from The Nature Conservancy who contributed to this research through interviews; research assistants Kyle Birchard, Tony Manzo, Matt Schwoebel, and Richard Tay; and three anonymous reviewers.

\section{LITERATURE CITED}

Agresti, A. 2002. Categorical data analysis. 2nd ed. Hoboken, NJ, USA: John Wiley and Sons. $710 \mathrm{p}$.

Anella, A., AND J. Wright. 2004. Saving the ranch: conservation easement design in the American West. Washington, DC, USA: Island Press. $173 \mathrm{p}$.

Barrett, T. S., and P. Livermore. 1983. The conservation easement in California. Covelo, CA, USA: Island Press. $173 \mathrm{p}$.

Barrett, T. S., and S. Nagel. 1996. The model conservation easement and historic preservation easement. Washington, DC, USA: Land Trust Alliance. $120 \mathrm{p}$.

Bartolome, J. W., W. F. Frost, N. K. McDougald, and M. Connor. 2002. California guidelines for residual dry matter (RDM) management on coastal and foothill annual rangelands. Oakland, CA, USA: Division of Agriculture and Natural Resources, University of California, Rangeland Monitoring Series. Publication 8092. $8 \mathrm{p}$.

Boyd, J., K. Caballero, and R. D. Simpson. 2000. The law and economics of habitat conservation: lessons from an analysis of easement acquisitions. Stanford Environmental Law Journal 19:209-255.

Brunson, M. W., AND L. Huntsinger. 2008. Ranching as a conservation strategy: can old ranchers save the new West? Rangeland Ecology and Management 61:137-147.

Byers, E., AND K. M. Ponte. 2005. The conservation easement handbook. 2nd ed. Washington, DC, and San Francisco, CA, USA: Land Trust Alliance and Trust for Public Land. $555 \mathrm{p}$.

California Department of Forestry and Fire Protection and US Forest Service. 2002. Land cover mapping and monitoring program: vegetation data. Available at: http://frap.cdf.ca.gov/maps.html. Accessed 2 October 2008.

Самасно, A. E. 2007. Can regulation evolve? Lessons from a study in maladaptive management. UCLA Law Review 55:293-358.

Carden, K. 2006. Bridging the divide: the role of science in species conservation law. Harvard Environmental Law Review 30:165-260.

Dana, S. T., and S. Fairfax. 1980. Forest and range policy: its development in the United States. 2nd ed. New York, NY, USA: McGraw-Hill. 458 p.

Doremus, H. 2007. Precaution, science, and learning while doing in natural resource management. Washington Law Review 82:547-579.

East Bay Regional Park District. 2001. Wildland management policies and guidelines. Oakland, CA, USA: East Bay Regional Park District. 46 p.

FairfaX, S. K., L. Gwin, M. A. King, L. Raymond, and L. Watt. 2005. Buying nature: the limits of land acquisition as a conservation strategy, 1780-2004. Cambridge, MA, USA: MIT Press. $357 \mathrm{p}$.

Fiorino, D. J. 2006. The new environmental regulation. Cambridge, MA, USA: MIT Press. 290 p.

Greene, D. M. 2005. Dynamic conservation easements: facing the problem of perpetuity in land conservation. Seattle University Law Review 28:883-923.

Gustanski, J. A., and R. H. Squires. 2000. Protecting the land: conservation easements past, present, and future. Washington, DC, USA: Island Press. $566 \mathrm{p}$.

Holling, C. S., And G. K. Meffe. 1996. Command and control and the pathology of natural resources. Conservation Biology 10:328-337.

HuntsingeR, L., AND L. Fortmann. 1990. California's privately owned oak woodlands: owners, use, and management. Journal of Range Management 43:147-152.

Huntsinger, L., AND P. Hopkinson. 1996. Sustaining rangeland landscapes: a social and ecological process. Journal of Range Management 49:167-173.

Jackson-Smith, D., U. Kreuter, and R. S. Krannich. 2005. Understanding the multidimensionality of property rights orientations: evidence from Utah and Texas ranchers. Society and Natural Resources 18:587-610.
Korngold, G. 2007. Solving the contentious issues of private conservation easements: promoting flexibility for the future and engaging the public land use process. Utah Law Review 4:1039-1084.

Kreuter, U. P., M. V. Nair, D. Jackson-Smith, J. R. Conner, and J. E. Johnston. 2006. Property rights orientations and rangeland management objectives: Texas, Utah, and Colorado. Rangeland Ecology and Management 59:632-639.

KRIPPENDORFF, K. 2004. Content analysis: an introduction to its methodology. 2nd ed. Thousand Oaks, CA, USA: Sage Publications. 413 p.

Kueppers, L. M., M. A. Snyder, L. C. Sloan, E. S. Zavaleta, and B. Fulfrost. 2005. Modeled regional climate change and California endemic oak ranges. Proceedings of the National Academy of Sciences of the United States of America 102:16281-16286.

LANGSTON, N. 2003. Where land and water meet: a Western landscape transformed. Seattle, WA, USA: University of Washington Press. 230 p.

LIPPMANN, J. 0. 2004. Exacted conservation easements: the hard case of endangered species protection. Journal of Environmental Law and Litigation 19:293-355.

[LTA] Land Trust Alliance. 2007. Amending conservation easements: evolving practices and legal principles. Washington, DC, USA: Land Trust Alliance. $118 \mathrm{p}$.

Macpherson, C. B. 1978. Property-mainstream and critical positions. Toronto, Canada: University of Toronto Press. 138 p.

Mahoney, J. D. 2002. Perpetual restrictions on land and the problem of the future. Virginia Law Review 88:739-787.

MARTY, J. 2005. Effects of cattle grazing on diversity in ephemeral wetlands. Conservation Biology 19:1626-1632.

Mashour, T., J. Alavalapati, R. Matta, S. Larkin, and D. Carter. 2005. A hedonic analysis of the effect of natural attributes and deed restrictions on the value of conservation easements. Forest Policy and Economics 7:771-781.

McLaughin, N. A. 2005. Rethinking the perpetual nature of conservation easements. Harvard Environmental Law Review 29:421-521.

Merenlender, A. M., L. Huntsinger, G. Guthey, and S. K. Fairfax. 2004. Land trusts and conservation easements: who is conserving what for whom? Conservation Biology 18:65-75.

NicolL, S. 2007. The death of rangeland reform. Journal of Environmental Law and Litigation 21:47-111.

Онм, В. W. 2000. The purchase of scenic easements and Wisconsin's great river road: a progress report on perpetuity. Journal of the American Planning Association 66:177-188.

Pavlik, B. M., P. C. Muick, S. G. Johnson, And M. Popper. 1991. Oaks of California. Los Olivos, CA, USA: Cachuma Press. 184 p.

Regan, H. M., M. Colyvan, and M. A. Burgman. 2002. A taxonomy and treatment of uncertainty for ecology and conservation biology. Ecological Applications 12:618-628.

Rissman, A. R., T. Comendant, L. Lozier, P. Kareiva, J. M. Kiesecker, M. R. Shaw, and A. M. Merenlender. 2007a. Conservation easements: private use and biodiversity protection. Conservation Biology 21:709-718.

Rissman, A. R., and A. M. Merenlender. 2008. The conservation contributions of conservation easements: analysis of the San Francisco Bay Area protected lands spatial database. Ecology and Society 13:40.

Rissman, A. R., R. Reiner, and A. M. Merenlender. 2007b. Monitoring natural resources on rangeland conservation easements. Rangelands 29:21-26.

Rose, C. 1994. Property and persuasion: essays on the history, theory, and rhetoric of property. Boulder, CO, USA: Westview Press. $317 \mathrm{p}$.

Stubble Height Review Team. 2006. Using stubble height to monitor riparian vegetation: a team of experts concludes that some past uses have been inappropriate. Rangelands 28:23-28.

Task Group on Unity in Concepts and Terminology Committee Members. 1995. New concepts for assessment of rangeland condition. Journal of Range Management 48:271-282.

Westoby, M., B. WalkeR, And I. Noy-Meir. 1989. Opportunistic management for rangelands not at equilibrium. Journal of Range Management 42:266-274.

Wilhere, G. F. 2002. Adaptive management in habitat conservation plans. Conservation Biology 16:20-29. 